\title{
Stereoselective Transformation of Phytosphingosine to Safingol
}

\author{
Nari Kim, Sun Hee Lee, and Sung Keon Namgoong \\ Department of Chemistru. Seoul Homen 's Cniversitw, Seoul 139-774. Korea. "E-mail: sknamâanuackn \\ Recerved December 31, 2008, Accepted February 4, 2009
}

\begin{abstract}
A short and efficient synthesis of $(2 S, 3 S)$-safingol fron conmercially available $D$-ribo- $(2 S, 3 S, 4 R)$-phytosphingosine is described. The highlights of the synthesis are a stereoselective one-pot transfomation of a diol into an epoxide under phase transfer cataly tic conditions and a regioselective epoxide-opening reduction with a hydride reagent.
\end{abstract}

Key Words: Safingol. Phytosphingosine. Phase transfer catalysiș. Epoxide-forming reaction. Reduction

\section{Introduction}

Safingol (1). (2S.35)-2-aminooctadecane-1.3-diol. an antineoplastic and antipsoriatic dnig. ${ }^{~}$ has been extensively investigated for its role in cell regulation, signal transduction. ${ }^{2}$ and inhibition of protein kinase $\mathrm{C}^{3}$. Furthermore, safingol enhances the cy totoxic effect of the chemotherapeutic agent mytomycin $\mathrm{C}$ by promoting drug-induced apoptosis. The effects of doxonibicin are also potentiated by co-administration of safingol.

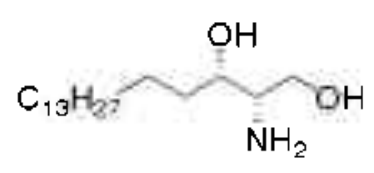

Safingol (1)

There are two general synthetic routes to safingol (1) reported in the literature diastereoselective or enantioselective methods ${ }^{\text {6a.e }}$ and practical resolution methods of racemic mixtures. Examples of stereoselective syntheses include: enantioselective Henry reaction ${ }^{6 a}$ of hexadecanal. followed by hydrogenation; an eight-step synthesis involving asymmetric borane reduction of a ketone moiety ${ }^{6 t}$ as a key step: stereoselective reduction of a chiral 2-acylaziridine intermediate: ${ }^{\text {Gc }}$ total synthesis starting from $(Z)$-but-2-ene-1. 4-diol ${ }^{\text {till }}$ and diastereoselective synthesis via nucleophilic addition to a chiral oxazolidinyl ester. ${ }^{\text {te }}$ Most recently safingol was prepared from protected glyceraldehydes. a trans-oxazoline derivative, and D-glycal ${ }^{5}$ through carbon chain extension strategies and efficient one-pot catalytic reduction of multifunctional groups. Most of the above-mentioned syntheses involve either multi-step reactions. including preparation steps for chiral ligands or auxiliaries. or generation of undesired stereoisomers. Our strategy is focused on efficient synthesis of an optically pure safingol by short reaction steps from L)-ribo-(2S,3S, $4 R)$-phy tosphingosine.

As a starting material. phỵ tosphingosine is a recently commercially available and inexpensive compound suitable for facile preparation of optically pure safingol without elaboration of the carbon chain backbone and with stereocontrol at C-2 position. This is the first example of a synthesis of safingol using phytosphingosine as a starting material as well as the shortest step sy nthesis for optically pure safingol among published synthetic methods.<smiles>NCC(O)C(O)C[18OH]</smiles>

Phytosphingosine

\section{Results and Discussion}

The present work is outlined in Scheme 1.

Compound 2 was obtained by a literature procedure ${ }^{1]}$ whereby treatment of phytosphingosine with ethyl benzimi date hydrochloride regioselectively produced protected diol 2, possessing an oxazoline moiety at the 1,2-position, in

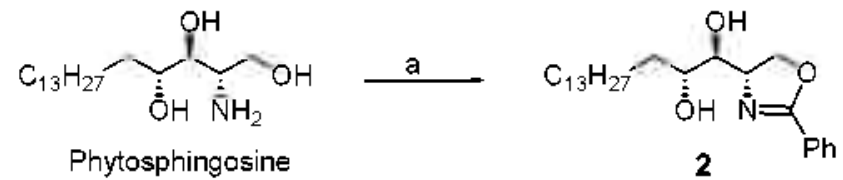

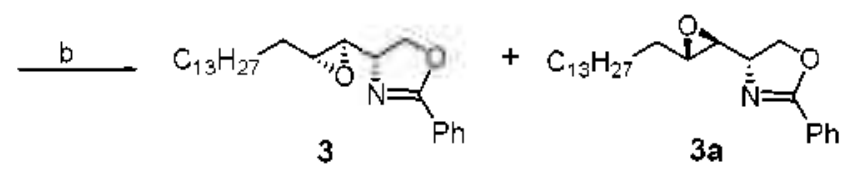

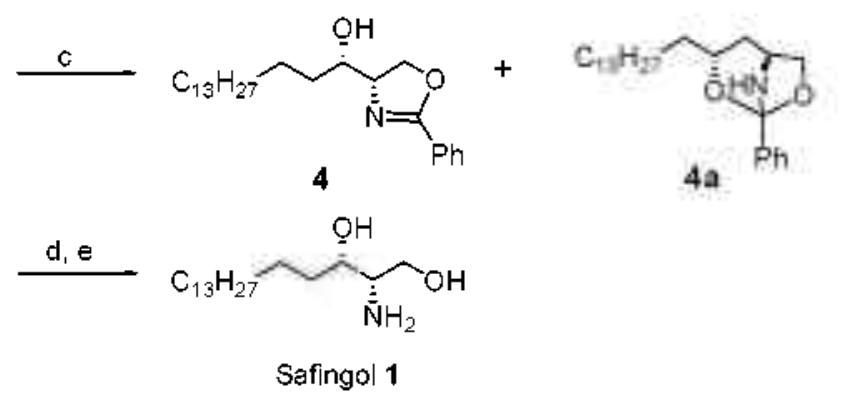

Scheme 1. Synthesis of safingol 1. Reagents and conditions: (a) PhC(NH)OEt:HCl, Et $t_{3} \mathrm{~N}, \mathrm{CH}_{2} \mathrm{Cl}_{2}$, reflux, $72 \mathrm{~h}, 91 \%$, (b) TsCl, $\mathrm{NaOH}$, TBAI, THF, 19 h, $71 \%(3), 10 \%$ (3a): (c) L-selectride (4 equiv), THF, $-10^{\circ} \mathrm{C}$ to RT, $10 \mathrm{~h}, 80 \%$ (4), 3\% (4a); (d) $2 \mathrm{MHCl}, \mathrm{THF}, 4 \mathrm{~h}$, (e) 12.5 $\mathrm{M} \mathrm{NaOH}, \mathrm{MeOH}$, reflux, 40 min, $78 \%$ 
excellent yield. This procedure effectively avoids several tedious protecting steps necessary to prepare the safingol precursor. In addition, the oxazoline group is expected to be stable under subsequent synthetic steps requiring strong, basic conditions.

The next step to retain the stereochemistry of 1 is to substitute the 4-hydroxyl group with hydrogen and invert the configuration of the 3-hydroxyl group of protected diol 2 . Epoxide 3 can fulfill this strategy as it can be converted to safingol precursor 4 after the epoxide-opening reaction at the less sterically hindered 4-position with an appropriate hydride donor.

At the current stage. either tosylation or mesylation of 2 . followed by intramolecular nucleophilic substitution by the adjacent hydroxyl group generally affords the $(35,45)$ epoxide 3 a as a major product in $c a .70 \%$ overall yield. instead of the desired ( $3 R, 4 R$ )-epoxide 3 . It is a well-known. two-step method to generate epoxide functionality in the field of phyt tosphingosine chemistry. 11.12 Therefore the stereoselective transformation of diol 2 into the ( $3 R .+R)$-epoxide 3 . one of the key intermediates is required for efficient synthesis of 1. Main strategy for the diastereoselective formation of 3 is to produce the kinetically-favored alkoxide ion through the 5 -membered ring chelation (A) between the lithium cation

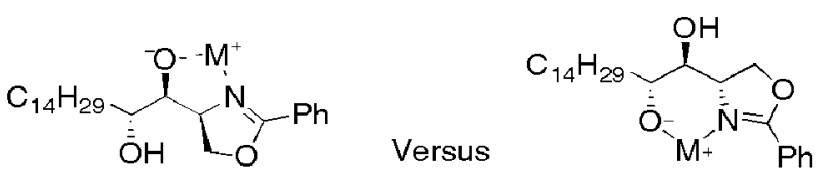

$$
\mathrm{M}^{+} \text {: metal cation }
$$

Figure 1. The chelation modes between $\mathrm{M}^{+}$and the $s p^{2}$-nitrogen of diol 2

Table 1. Stereoselective transfomation reactions of diol 2 to epoxide 3.

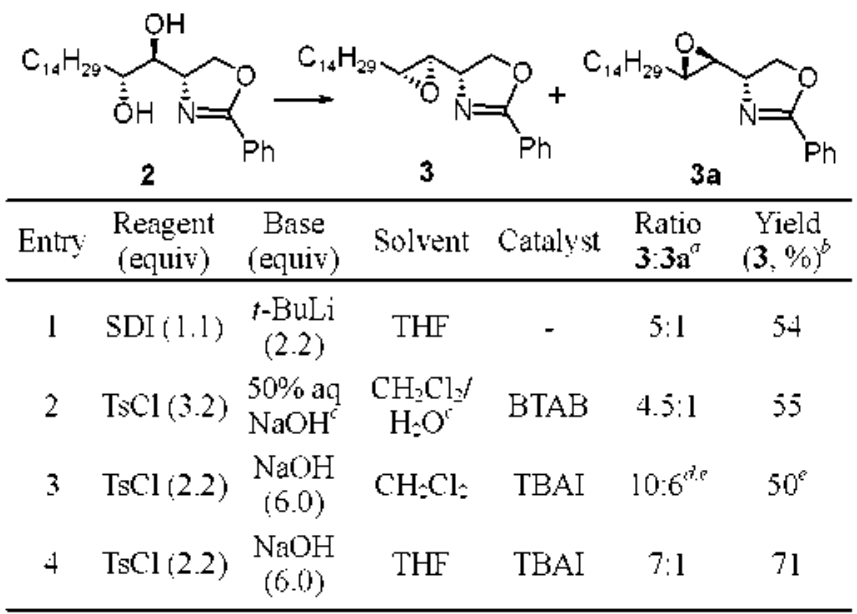

"Average ratio detemined by 'H-NMR analysis. "Isolated vield of 3 after purification by column chromatography. "Szeja's reaction condition: excess of $50^{\circ} .6$ aqueous $\mathrm{NaOH}$ was used. "Ratio of 3 and the epoxideopened side product induced by the dichloromethanide anion as an

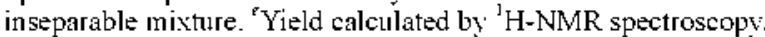

$\mathrm{SDI}=1.1^{\prime}$-sulfonyldimidazole; $\mathrm{TsCl}=p$-toluenesulfonyl chloride: $\mathrm{BTAB}$ $=$ benzyltriethylanmonium bronide; TBAI = tetrabutylannnonium iodide. and $s p^{2}$-nitrogen, instead of the 6-membered ring chelation (B) resulting from deprotonation at the 4-hydroxyl group as shown in Fig. 1. A generation of this alkoxide ion intermediate under strong. basic condition facilitates introduction of leaving group at the 3-position of 2 . and subsequent nucleophilic substitution with inversion of configuration at this position. providing required epoxide 3 .

Several one-pot transfonmation reactions of 2 into 3 were ultimately screened after considerable research efforts and their results are summarized in Table 1.

One such transformation began with the reaction of 2 with $1 . l^{\prime}$-sulfonyldimimazole/t-butyllithium. ${ }^{\text {l*i.l. }}$ It provided epoxide 3 and the diastereomer $3 \mathbf{a}$ in a respective ratio of $5: 1$ and an isolated yield of $54 \%$ for 3 (Table 1 , entry 1 ). The most difficult issue to overcome was the selection of the solvent systems for chromatography in order to separate $\mathbf{3}$ from $\mathbf{3 a}$. We found chloroform ethyl acetate $(10: 1, v / v)$ to be the appropriate solvent system.

Another one-pot transformation of 2 into 3 utilizes $p$ toluenesulfonyl chloride in $\mathrm{CH}_{2} \mathrm{Cl}_{2} / \mathrm{NaOH}$ (aq) under liquidliquid phase transfer catalytic (PTC) conditions. These conditions originated from Szeja s procedure ${ }^{14}$ that involve the functional group transformation of simple cyclic or acyclic diols into corresponding epoxides (Table 1 , entry 2). In the cases of the PTC reactions applying Szeja's procedure, aqueous $\mathrm{NaOH}$ seems not only to hydrolyze $p$-toluenesulfonyl chloride but also to produce a large anount ( $24 \% \mathrm{yield}$ ) of the side product tosylated at both the 3- and 4-positons of 2. To overcome such obstacles. a solid-liquid PTC reaction in $\mathrm{CH}_{2} \mathrm{Cl}_{2}$ was explored, as shown in Table 1. Unfortunately. this generated a considerable amount of an inseparable epoxide ring-opened side product derived from the further reaction between 3 and the dichloromethanide anion. Due to formation of this ring-opened side product. the reaction resulted in a lower diastereoselectivity and yield of 3 than those of the liquid-liquid PTC reaction (Table 1 , entry 3). The modified process to mininuize the aforementioned problems was to treat 2 with both powdered $\mathrm{NaOH}$ and THF, as the base and solvent. under solid-liquid PTC conditions. Application of this procedure led to superior diastereoselectivity $(7: 1)$ between $\mathbf{3}$ and $\mathbf{3 a}$ and an enhanced yield $(71 \%)$ of $\mathbf{3}$ as compared with the other results in Table 1 (entry 4). The good stereoselectivity can be also suggested by the above chelation model which is replaced lithum cation with quatemary ammonium ion. In this case. molecular model of the chelation mode (B) shows much severer steric hindrance between long chain alkyl group and butyl group of catalyst than that of the chelation mode (A). Therefore, the quaternary ammonium ion can facilitate to form a 5 -membered ring chelated complex more readily than 6 -membered ring complex. In addition this modified PTC reaction furnished the least amount of side products in contrast with the other three epoxide-forning reactions. Consequently, it was the most promising reaction to generate epoxide $\mathbf{3}$ from diol $\mathbf{2}$ in a single step.

The second key intermediate. 4 , was prepared from an epoxide-opening reduction of $\mathbf{3}$ with a wide range of hydride nucleophiles with their results summarized in Table 2.

Nucleophilic ring-opening reductions of the epoxide groups 
Table 2. Reduction of 3 with typical hydride reagents.

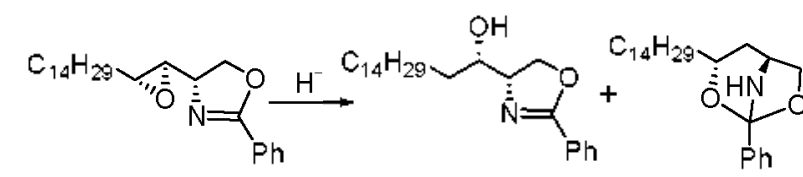

3

\begin{tabular}{ccccc}
\hline Entry & $\begin{array}{c}\text { Reducing } \\
\text { agent }\end{array}$ & Equivalent & $\begin{array}{c}\text { Ratio } \\
4: 4 a^{b}\end{array}$ & $\begin{array}{c}\text { Yield } \\
(4, \%)^{c}\end{array}$ \\
\hline 1 & $\mathrm{LiBH}_{4}$ & 4.0 & $\mathrm{NR}^{d}$ & - \\
2 & $\mathrm{Red}-\mathrm{A} l^{6}$ & 4.0 & $\mathrm{NR}$ & - \\
3 & $(i-\mathrm{Bu})_{2} \mathrm{AlH}$ & 3.0 & $\mathrm{NR}$ & - \\
4 & $\mathrm{LiAlH}$ & $1.1 \sim 2.4$ & $2: 1 \sim 1: 2^{*}$ & $\leq 40$ \\
5 & $\mathrm{Li}(\mathrm{Et})_{3} \mathrm{BH}$ & 4.0 & $7: 3$ & 61 \\
6 & $\mathrm{Li}(\mathrm{sec}-\mathrm{Bu})_{3} \mathrm{BH}$ & 4.0 & $26: 1$ & 80
\end{tabular}

${ }^{a}$ Reductions carried out in THF from $-15^{\circ} \mathrm{C}$ to RT. ${ }^{h}$ Average ratio observed by proton NMR spectroscopy. "Isolated yield of 4 after purification by recrystallization in methanol. "No reaction occurred. "Variable ratio according to the equivalents of $\mathrm{LiAlH}_{4}$ used. Red-Al ${ }^{\mathrm{E}}$ ' $=$ sodium bis(2-nethoxyethoxy)aluminum hydride. The average ratio deternined by 'H-NMR analysis

in phy'tosphingosine derivatives are believed to occur regioselectively from preferential attack of hydride species at the less sterically hindered $\mathrm{C}-4$ position. ${ }^{15-6-c}$ However. depending on nature of the hydride reagent, reduction of epoxide 3 to form corresponding alcohol 4 did not show a similar tendency toward previous cases. Epoxide $\mathbf{3}$ was resistant to reductions with both lithium borolydride and Red-Al ${ }^{\mathbb{E}}$ [sodium bis(2methoxyethoxy) aluminum hydride]. possibly as a result of the lower reducing power of $\mathrm{LiBH}_{4}$ and steric hindrance of Red-Al ${ }^{\mathbb{E}}$ (Table 2, entries I and 2). In particular. unsuccessful DIBAL-H (diisobuty laluminum hydride) reduction of 3 was an exceptional case, because reductions with DIBAL-H have been reliably achieved with most of the epoxides. ${ }^{150.6}$ Probably, reduction does not work as the second equivalent of DBAL-H is unable to approach the $\mathrm{C}-4$ position due to severe steric hindrance caused by a tight coordination of neutral DIBAL-H to the $s p^{2}$-nitrogen of $\mathbf{3}$ (Table 2, entry 3). Thus, a series of other lyydride reagents were examined. In the case of $\mathrm{LiAlH}_{4}$, the ratio of $4:$ ta varied from $2: 1$ to $1: 2$, with 4 decreasing as the amount of reducing agent was increased to complete the reaction. Side product $4 \mathrm{a}$ is inevitably formed while the reduction of 3 works well with the hydride nucleophile. The side reaction proceeds via nucleophilic attack of a $\mathrm{C}-4$ alkoxide ion generated in situ at a reduction stage to an electrophilic site in the oxazoline moiety. leading directly to cyclization of the intermediate (Table 2. entry 4). The stnicture of 4a was verified by COSY experiments and mass spectrometry. although it was a mixture with 4 . Alcohol 4 was isolated from ta after purification by recrystallization in methanol. These mixtures were not able to be separated by column chromatography due to their same polarities in any solvents. Conversely. super-hydride (lithium triethylborohydride) reduction ${ }^{16}$ gave alcohol $t$ as the major product with better regioselectivity $(c a .7: 3)$ and a higher yield $(61 \%)$ than those of $\mathrm{LiAlH}_{4}$ reduction (Table 2. entry' 5). Surprisingly' the best result came from L-selectride [lithium tri(sec-butyl)- borohydride] reduction, exhibiting an excellent regioselectivity of $26: 1$ (4:4a). together with an optimum yield of $80 \%$ (Table 2. entry 6). L-Selectride is often a more regioselective reducing agent than super-hydride. displaying both superior regioselectivity and better yield. ${ }^{15}$ It proved to be the most useful and regioselective reducing agent as well among the hydride reagents used in the epoxide-opening reaction of 3 . The use of 4.0 equivalents of $\mathrm{L}$-selectride was a critical factor to complete the reduction and to achieve optimum yield.

Finally. the deprotection reaction of $\mathbf{4}$ in acidic medium followed by basic hydrolysis gave the optically pure safingol (1) in $78 \%$ yield after either washing the reaction residue with $\mathrm{CHCl}_{\mathfrak{s}}$ or purification by column cluromatography (clloroform: methanol:ammonia (aq), $60: 10: 4$ ). All the spectral data of the final conpound prepared were identical with the reference data of safingol (1) ${ }^{6,3}$ This has been the shortest step synthesis for optically pure safingol since its synthetic procedures were first published.

\section{Conclusion}

Herein, this synthesis of safingol (1) is first to be achieved efficiently from commercially available phytosphingosine in just over five steps and a $40 \%$ overall yield. The key steps were the stereoselective one-pot transformation of diol $\mathbf{2}$ into epoxide 3 under PTC conditions and the regioselective ring-opening reduction of epoxide 3 with L-selectride.

\section{Experimental Section}

General methods. All reactions were carried out under nitrogen atmosphere. $\mathrm{D}-r i b o-(2 S, 3 S,+R)$-Phytosphingosine was obtained from Doosan Biotech BU (JP Chem). Korea. Tetrahydrofuran was freshly distilled immediately before use. Other solvents were dried over either $\mathrm{MgSO}_{4}$ or $\mathrm{Na}_{2} \mathrm{SO}_{4}$ before use. All other reagents were purchased from commercial sources and used without further purification, unless specifically stated.

All reactions were monitored by thin layer cluromatography with Merck silica gel $60 \mathrm{~F}_{354}$. Flash chromatogmaphy was performed on Merck Kiesegel 60 flash silica gel (E. Merck. Art $7734.70 \cdot 230 \mathrm{mesh}$ ). Yields refer to chromatographically and spectroscopically pure compounds. unless otherwise noted.

${ }^{1} \mathrm{H}$ and ${ }^{12} \mathrm{C}$ NMR spectra were recorded on a Bruker, Avance 600 spectrometer or a Bnuker. Avance 500. as noted in the experimental for each compound. Chemical shifts are reported relative to the residue peaks of the solvent $\left(\mathrm{CDCl}_{3}\right.$ : $7.26 \mathrm{ppm}$ for ${ }^{1} \mathrm{H}$ and $77.0 \mathrm{ppm}$ for $\left.{ }^{13} \mathrm{C}\right),\left(\mathrm{CD}_{3} \mathrm{OD}: 3.3 \mathrm{ppm}\right.$ for ${ }^{1} \mathrm{H}$ and $49.0 \mathrm{ppm}$ for $\left.{ }^{12} \mathrm{C}\right)$. The following abbreviations are used to denote the multiplicities: $\mathrm{s}=$ singlet. $\mathrm{d}=$ doublet. $\mathrm{dd}=$ doublet of doublets. $\mathrm{t}=$ triplet. $\mathrm{q}=$ quartet, $\mathrm{br}=$ broad and $\mathrm{m}=$ multiplet. Diastereomeric ratios were deternined by ${ }^{l} \mathrm{H}$ NMR $(600 \mathrm{MHz})$ analyses of the mixtures isolated by column chromatography. Melting points were obtained using a Stuart SMP3 (Barloworld scientific Ltd.) and are uncorrected. Infrared spectra were recorded by the $\mathrm{KBr}$ pellet method on a Perkin Elmer spectnum 100 in range of $4000-400 \mathrm{~cm}^{-1}$. Optical rotations were recorded on an AUTOPOL III digital 
polarimeter at $546 \mathrm{~nm}$ and reported as follows: concentration $(c$ in $\mathrm{g} / 100 \mathrm{~mL}$ ) and solvent. High resolution mass-spectra were obtained on a JEOL JMS600 spectrometer at Mass Spectrometry Laboratory in Seoul National University.

2-Phenyl-(4S)-[(1S,2R)-1,2-dihydroxyhexadecyl $]-1,3-0 x a-$ zoline (2). To a stirred suspension of D-ribo-(2S, 3S. $4 R)$ phytosphingosine $(6.01 \mathrm{~g} .18 .9 \mathrm{mmol})$ and ethyl benzimidate hydrochloride $(4.22 \mathrm{~g}, 22.7 \mathrm{mmol})$ in dichloromethane (135 $\mathrm{mL})$ was added triethylamine $(3.20 \mathrm{~mL} .22 .7 \mathrm{mmol})$. The reaction mixture was stirred for $72 \mathrm{~h}$ at $40^{\circ} \mathrm{C}$ and cooled to room temperature. The insoluble product was filtered and recrystallized from methanol to give diol $2(6.95 \mathrm{~g} .91 \%)$ as a white crystal.

$R_{\mathrm{f}}: 0.58$ (chloroform:methanol. 9:1): mp 137-139 "C. lit ${ }^{11}$ $137-138^{\circ} \mathrm{C} ;[\alpha] 30.6\left(c 0.22 . \mathrm{CHCl}_{3}, \mathrm{CH}_{3} \mathrm{OH}, 5: 1, v / v\right), \mathrm{lit}^{11}$ [a] 24.8 (c 1.60, $\mathrm{CHCl}_{3}: \mathrm{CH}_{3} \mathrm{OH}$. 5:1. v/v); IR (thin film. KBr): 3325, 3071, 2954, 2922, 2851, 1645, 1604, 1582, 1499. $1468 \mathrm{~cm}^{-1}$; ${ }^{1} \mathrm{H}$ NMR $\left(500 \mathrm{MHz}, \mathrm{CDCl}_{3}\right.$ ): ò 7.95-7.86 (d. $2 \mathrm{H}, J$ $=7.4 \mathrm{~Hz} . \mathrm{Ph}), 7.50-7.43(\mathrm{~m} . \mathrm{lH} . \mathrm{Ph}), 7.43-7.35(\mathrm{~m} .2 \mathrm{H} . \mathrm{Ph})$. $4.60-4.50$ (m. 1H). $4.50-4.45$ (m. $1 \mathrm{H}) .4 .45-4.37$ (m. $1 \mathrm{H})$. $3.87-3.80(\mathrm{~m}, \mathrm{lH}) .3 .75-3.68$ (t. $\left.\mathrm{lH}, J=5.8 \mathrm{~Hz}, \mathrm{H}_{3}\right) .3 .28-3.20$ (brs. $\mathrm{IH}, \mathrm{OH}$ ). 2.28-2.10 (brs. $\mathrm{IH}, \mathrm{OH}), 1.75-1.65$ (m. $\mathrm{IH}$. $\left.\mathrm{H}_{3}\right)$. 1.54-1.45 (m. 1H. $\left.\mathrm{H}_{5}\right)$. 1.45-1.18 (m, 24H, (CH $\left.)_{12}\right)$. $0.91-0.85$ (t. $\left.3 \mathrm{H}, J=6.7 \mathrm{~Hz}, \mathrm{CH}_{3}\right):{ }^{17} \mathrm{C}$ NMR $(126 \mathrm{MHz}$. $\left.\mathrm{CDCl}_{3}\right): \delta 165.6,131.9,128.6,127.4,75.9 .74 .2,70.2,69.6$. 33.2. 32.1. 29.9. 29.9. 29.8. 29.6, 25.6, 22.9. $14.3 \mathrm{ppm}$ : HRMS $\left(\mathrm{FAB}^{-}\right.$) calculated for $\mathrm{C}_{\unlhd 5} \mathrm{H}_{43} \mathrm{O}_{3} \mathrm{~N} .404 .3165[\mathrm{M}+1]^{-}$ $m z$ : observed, $404.3164[\mathrm{M}+1]^{-} m z$.

2-Phenyl-(4S)-[(1R,2R)-1,2-epoxyhexadecyl]-1,3-oxazoline (3). To a mixture of diol $2(5.00 \mathrm{~g}, 12.4 \mathrm{mmol})$, tetrabutylammonium iodide (234 mg. $0.62 \mathrm{mmol}$ ) and $\mathrm{NaOH}(4.96 \mathrm{~g}$. $12+\mathrm{mmol}$ ) in THF ( $1+0 \mathrm{~mL})$. was added $p$-toluenesulfonyl chloride $(2.627 \mathrm{~g} .13 .8 \mathrm{mmol})$. The reaction mixture was stirred for $10 \mathrm{~h}$. p-Toluenesulfonyl chloride $(2.627 \mathrm{~g} .13 .8$ mmol) in dichloromethane $(20 \mathrm{~mL})$ was then added to the reaction mixture and the resulting mixture stirred for an additional $9 \mathrm{~h}$. The insoluble residue was removed from the reaction mixture by filtration. The solution was diluted with dichloromethane $(300 \mathrm{~mL})$ and the dichloromethane washed with water $(100 \mathrm{~mL})$. The organic layer was dried $\left(\mathrm{MgSO}_{4}\right)$ and evaporated in vactro. The residue was purified by flash column chromatography (chloroformethyl acetate. $40: 1$ to $10: 1)$ to give epoxide $3(3.40 \mathrm{~g} .71 \%)$ and $3 \mathrm{a}(0.48 \mathrm{~g} .10 \%)$ as a white powder.

$R_{\mathrm{f}}: 0.60$ (chloroform ethyl acetate $10: 1$ ): mp $63-65^{\circ} \mathrm{C}:[\alpha]$ 94.1 (c 1.01, $\mathrm{CHCl}_{3}$ ): IR (thin film. KBr): 2957. 2918. 2851 . 1655. 1640. 1579, 1495. 1471. $1450 \mathrm{~cm}^{-1} ;{ }^{1} \mathrm{H}$ NMR $(600$ $\mathrm{MHz}, \mathrm{CDCl}_{3}$ ): $\hat{o} 7.98-7.91$ (d. $\left.2 \mathrm{H}, J=7.2 \mathrm{~Hz} . \mathrm{Ph}\right), 7.5 \mathrm{I}-7.45$ (m, 1H, Ph). 7.44-7.37 (m. 2H. Ph), 4.54-4.43 (m, 2H, $\mathrm{H}_{1}$ and $\left.\mathrm{H}_{2}\right), 4.31-4.2+\left(\mathrm{m}, \mathrm{IH}, \mathrm{H}_{1}\right), 3.09-3.02$ (td. $\mathrm{IH}, J=5.7$ and 1.8 Hz. $\mathrm{H}_{4}$ ), 2.99-2.92 (m. 1H. $\mathrm{H}_{3}$ ), 1.60-1.53 (m, 1H, $\mathrm{H}_{5}$ ). $1.50-1.36$ (m. 1H. $\mathrm{H}_{5}$ ). 1.36-1.19 (m. 2+H. (CHs) $\left.)_{12}\right) .0 .91-$ 0.85 (t. $\left.3 \mathrm{H} . J=7.2 \mathrm{~Hz}, \mathrm{CH}_{3}\right):{ }^{13} \mathrm{C} \mathrm{NMR}\left(126 \mathrm{MHz} \mathrm{CDCl}_{3}\right): \delta$ 165.4. 131.7, 128.6, 128.5, 127.7,69.2,66.6. 59.4. 56.0, 32.1, $31.9 .29 .9 .29 .9 .29 .9 .29 .8,29.8 .29 .7 .29 .6,29.6,26.2 .22 .9$ 14.3 ppm; HRMS $\left(\mathrm{FAB}^{+}\right.$) calculated for $\mathrm{C}_{2}: \mathrm{H}_{410} \mathrm{O}_{2} \mathrm{~N} .386 .3059$ $[\mathrm{M}+1]^{-} m: z$ : observed. $386.3057[\mathrm{M}+1]^{-} \mathrm{m} / \mathrm{z}$

2-Phenyl-(4S)-[(1S,2S)-1,2-epoxyhexadecyl]-1,3-oxazoline (3a). $R_{\mathrm{f}}, 0.68$ (clloroforntethyl acetate, $10: 1$ ): $\mathrm{mp} 70-73^{\circ} \mathrm{C}$. $\mathrm{lit}^{1 \mathrm{1}} 63-64 \mathrm{C}:[\alpha]+5.8\left(c 1.04 . \mathrm{CHCl}_{3}\right)$. lit ${ }^{1]}[\alpha] 24.8$ (c l.60. $\mathrm{CHCl}_{2}: \mathrm{CH}_{3} \mathrm{OH}, 5: 1 . \mathrm{v} / \mathrm{v}$ ); IR (thin film. $\mathrm{KBr}$ ): $2957,2918$. $2851,1655.1640 .1579,1495,1471.1450 \mathrm{~cm}^{-1} ;{ }^{l} \mathrm{H}$ NMR $\left(600 \mathrm{MHz}, \mathrm{CDCl}_{3}\right): \delta 8.99-7.93$ (d. $2 \mathrm{H}, J=7.8 \mathrm{~Hz}, \mathrm{Ph}$ ). 7.52-7.47 (m, 1H. Ph), 7.45-7.38 (n. 2H, Ph). 4.51-4.4t (m, lH. $\left.\mathrm{H}_{\mathrm{l}}\right), 4.36-4.30\left(\mathrm{t} . J=7.8 \mathrm{~Hz}, 1 \mathrm{H}, \mathrm{H}_{\mathrm{l}}\right), 4.24-4.16(\mathrm{~m}, \mathrm{lH}$, $\left.\mathrm{H}_{2}\right), 2.96-2.91$ (n. $\left.1 \mathrm{H}, \mathrm{H}_{4}\right) .2 .90-2.85$ (dd, $1 \mathrm{H} . J_{2.3}=6.0 \mathrm{~Hz}$, $\left.J_{3,4}=1.8 \mathrm{~Hz}, \mathrm{H}_{3}\right), 1.69-\mathrm{l} .63\left(\mathrm{~m}, \mathrm{lH}, \mathrm{H}_{5}\right), 1.59-\mathrm{l} .5 \mathrm{l}\left(\mathrm{m}, \mathrm{lH}, \mathrm{H}_{5}\right)$. $1.41-1.19\left(\mathrm{~m}, 2+\mathrm{H}_{0}\left(\mathrm{CH}_{2}\right)_{12}\right), 0.90-0.85$ (t. $3 \mathrm{H}, J=6.6 \mathrm{~Hz}$. $\left.\mathrm{CH}_{3}\right) \mathrm{ppm}$.

2-Phenyl-(4S)-[(1S)-1-hydioxyhexadecyl]-1,3-oxazoline (4). To a solution of epoxide 3 ( $1.00 \mathrm{~g} .2 .602 \mathrm{mmol}$ ) in THF $(50 \mathrm{~mL})$ was added L-selectride ( $1.0 \mathrm{M}$ in THF. $10.4 \mathrm{~mL} .10 .4$ mmol) at $-10^{\circ} \mathrm{C}$. The reaction mixture was stirred for $7 \mathrm{~h}$ at this temperature and maintained at RT for additional $3 \mathrm{~h}$. The reaction was quenched with aqueous $\mathrm{NaOH}$ solution $(20 \mathrm{~mL})$. The resulting solution was diluted with dichloromethane (100 $\mathrm{mL}$ ) and the dichloromethane washed with water $(50 \mathrm{~mL})$. dried $\left(\mathrm{MgSO}_{4}\right)$ and evaporated in vacuo. The residue was filtered through a silica gel eluted with ethyl acetate and the filtrate was concentrated in vacuo. The resulting residue was washed with methanol $(25 \mathrm{~mL})$ to remove $t a$ and to give alcohol $+(0.8 \mathrm{lg} .80 \%)$ as a white crystal.

$R_{\text {: }} 0.37$ (chloroformtethyl acetate, $10: 1$ ): np $114-115^{\circ} \mathrm{C}$; [a] $73.0\left(c 1.02 . \mathrm{CHCl}_{3}\right)$ : IR (thin film. KBr): 3163.2929. $2850,1643.1469,1455.1381 \mathrm{~cm}^{-1} ;{ }^{1} \mathrm{H}$ NMR $(600 \mathrm{MHz}$, $\mathrm{CDCl}_{3}$ ): $\delta 7.98-7.92$ (d. $2 \mathrm{H}, J=7.8 \mathrm{~Hz}$. Ph). $7.52-7.45$ (n. $1 \mathrm{H}$, $\mathrm{Ph}) .7 .45-7.37(\mathrm{~m} .2 \mathrm{H}, \mathrm{Ph}) .4 .53-4.44\left(\mathrm{~m} . \mathrm{lH}, \mathrm{H}_{3}\right)$. 4.29-4.22 (m. $\left.1 \mathrm{H}, \mathrm{H}_{2}\right) .+22-4.15\left(\mathrm{n}, 1 \mathrm{H}, \mathrm{H}_{1}\right) .3 .55-3.47\left(\mathrm{~m}, 1 \mathrm{H} . \mathrm{H}_{3}\right)$, $2.31-2.23$ (d. IH, $J=5.4 \mathrm{~Hz}, \mathrm{OH}$ ) $1.58-\mathrm{l} .48$ (m. $2 \mathrm{H}$ ). $1.48-1.17\left(\mathrm{~m}, 26 \mathrm{H},\left(\mathrm{CH}_{2}\right)_{13}\right), 0.92-0.83$ (t. $3 \mathrm{H},{ }^{2} \mathrm{~J}=6.6 \mathrm{~Hz}$, $\left.\mathrm{CH}_{3}\right):{ }^{12} \mathrm{C}$ NMR $\left(151 \mathrm{MHz}, \mathrm{CDCl}_{3}\right): \delta$ 165.0, 131.6, 128.4. $128.4 .127 .4,74.2,71.6,69.8,34.2,31.9 .29 .7,29.7,29.6$, $29.6,29.4,25.8,22.7,14.1 \mathrm{ppm}$ : $\mathrm{HRMS}\left(\mathrm{CI}^{+}\right)$calculated for $\mathrm{C}_{25} \mathrm{H}_{42} \mathrm{O}_{2} \mathrm{~N}, \quad 388.3215[\mathrm{M}+\mathrm{l}]^{+} \mathrm{mz}$ : observed, 388.3213 $[\mathrm{M}+1]^{-} \mathrm{m}: \mathrm{z}$.

$(1 R, 3 R,+S, 5 S)$-1-Phenyl-3-tetradecyl-2,7,8-dioxazabicyclo[3.2.1]octan- -0 -o] (4a, a mixture with $\downarrow$ ). $R_{\mathrm{f}}: 0.37$ (chloroform:ethyl acetate, $10: 1)$ : ${ }^{1} \mathrm{H}$ NMR $\left(600 \mathrm{MHz} . \mathrm{CDCl}_{3}\right)$ : $\delta$ $7.93-7.89$ (d. $2 \mathrm{H}, J=7.8 \mathrm{~Hz}, \mathrm{Ph}$ ). $7.55-7.46$ (m. lH, Ph). 7.42-7.37 (n. 2H, Pl). 4.89-4.85 (s. 1H. NH), 4.63-4.57 (dd, IH. $J=9.6$ and $\left.8.7 \mathrm{~Hz}, \mathrm{H}_{\mathrm{l}}\right), 4.48-4.4 \mathrm{l}\left(\mathrm{m}, \mathrm{lH}, \mathrm{H}_{2}\right), 4.03-3.96$ (m. $2 \mathrm{H} . \mathrm{H}_{1}$ and $\mathrm{H}_{4}$ ). $1.88-1.82$ (ddd, $1 \mathrm{H}, J=13.5 .3 .6$ and 1.2 $\left.\mathrm{Hz}, \mathrm{H}_{3}\right), \mathrm{l} .63-\mathrm{I} .50\left(\mathrm{~m}, 2 \mathrm{H}, \mathrm{H}_{3}\right.$ and $\left.\mathrm{H}_{3}\right), 1.50-\mathrm{l} .40(\mathrm{~m}, \mathrm{lH}$, $\left.\mathrm{H}_{5}\right) .1 .40-1.20\left(\mathrm{ml} .2+\mathrm{H} .\left(\mathrm{CH}_{2}\right)_{12}\right) .0 .90-0.85$ (t. $3 \mathrm{H} . J=6.6 \mathrm{~Hz}$. $\left.\mathrm{CH}_{3}\right):{ }^{12} \mathrm{C}$ NMR (151 MHz. $\left.\mathrm{CDCl}_{3}\right): \delta 163.8,131.7,128.3$, 127.1.73.3.71.8.66.7,43.1. 37.6.31.9.29.7. 29.7, 29.4. 25.5. 22.7. 14.1 ppm: $\mathrm{MS}\left(\mathrm{FAB}^{+}\right): m z(\%): 388(100)[\mathrm{M}+1]^{-}, 105$ (53).

(2S,3S)-2-Aminooctadecane-1,3-diol (safingol, 1). To a solution of alcohol $+(178 \mathrm{mg} .0 .460 \mathrm{mmol})$ in THF (10 mL) was added aqueous $\mathrm{HCl}$ ( $2 \mathrm{M}, 2.5 \mathrm{~mL}$ ). The reaction mixture was stirred for $t h$ and the solvents were evaporated in vacuo. The resulting residue was used for next reaction without further purification. The residue was dissolved in methanol (10 mL)/aqueous $\mathrm{NaOH}(12.5 \mathrm{M} .4 .2 \mathrm{~mL}$ ) and the reaction mixture refluxed for $40 \mathrm{~min}$. The solvents were concentrated 
in vacuo and the residue partitioned into dichloromethane (50 $\mathrm{mL}$ ) and water $(10 \mathrm{~mL})$. The combined organic layers were dried $\left(\mathrm{MgSO}_{4}\right.$ ) and concentrated in vacuo. The residue was purified by either washing it with chloroform ( $10 \mathrm{~mL}$ ) or flash column chromatography (chloroform methanol:ammonia (aq.). $40: 1: 0$ to $6: 1: 0.4)$ to give safingol $1(108 \mathrm{mg}, 78 \%$ ).

$R_{\mathrm{f}}: 0.06$ (chloroform:methanol. 5:1): mp $109-110^{\circ} \mathrm{C}$. lit $107-109^{\circ} \mathrm{C} ;[\alpha]-11.2\left(c 0.10 . \mathrm{CHCl}_{3}: \mathrm{CH}_{3} \mathrm{OH} .10: 1, v / v\right)$, lit $^{\text {6a }}$ $[\alpha]_{D}-11.05\left(c 0.29, \mathrm{CHCl}_{3}: \mathrm{CH}_{3} \mathrm{OH}, 10: 1, \mathrm{v} / \mathrm{v}, 97 \%\right.$ ee): IR (thin film. KBr) 3365. 3314. 2955, 2918. 2852, 1579. 1468 $\mathrm{m}^{\cdot{ }^{-1}:}$ : H NMR $\left(600 \mathrm{MHz} . \mathrm{CD}_{3} \mathrm{OD}\right): \delta 3.64-3.56\left(\mathrm{dd} .1 \mathrm{H} . J_{1.1}=\right.$ $\left.10.8 \mathrm{~Hz}, J_{1.2}=4.8 \mathrm{~Hz}, \mathrm{H}_{1}\right), 3.56-3.49\left(\mathrm{~m}, \mathrm{IH}, \mathrm{H}_{3}\right), 3.49-3.43$ (dd. $\left.1 \mathrm{H}, J_{1} .=6.6 \mathrm{~Hz}, \mathrm{H}_{1}\right) .2 .68-2.59\left(\mathrm{~m}, 1 \mathrm{H} . \mathrm{H}_{2}\right) .1 .40-1.20$ (m. 28H. $\left.\left(\mathrm{CH}_{2}\right)_{14}\right), 0.91-0.85$ (t. $\left.3 \mathrm{H}, J=7.2 \mathrm{~Hz}, \mathrm{CH}_{3}\right) ;{ }^{13} \mathrm{C}$ NMR (151 MHz, $\left.\mathrm{CD}_{3} \mathrm{OD}\right)$; ò $72.7,65.0,58.0,35.0 .33 .2$, $31.0 .27 .1,23.9 .14 .6 \mathrm{ppm}$; $\mathrm{HRMS}\left(\mathrm{CI}^{+}\right)$calculated for $\mathrm{C}_{18} \mathrm{H}_{4 \mathrm{c}}$ $\mathrm{O}_{2} \mathrm{~N}, 302.3059[\mathrm{M}+\mathrm{l}]^{+} \mathrm{m} z \mathrm{z}$ : observed $302.3058[\mathrm{M}+\mathrm{l}]^{-} \mathrm{m} \cdot \mathrm{z}$.

Acknow ledgments. This work was supported by a research grant from Seoul Women's University (2007).

\section{References}

1. USP Dictionary of USAN and Intenational Drig Kames: US Phamcopia: Rockville, MD, 2000; p 636.

2. Hannun, Y. A. Bell, R. M. Science 1989, 243, 500-507.

3. Schwartz, G. K : Tiang, T.; Kelsen, D. P: Albino, A. P. J. Katl. Cancer Ihst 1993, 85, 402-407.

4. Schwartz, G. K: Hainovitz-Friednan, A.: Dhupar, S. K.: Ehleiter, D.; Maslak, P.; Lawrence, L.; Loganzo, F.; Kelsen, D. P.; Fuks, Z.; Albino, A. P. J. Katl Cancer Inst. 1995, 87, $1394-1399$

5. Schwartz, G. K.: Ward, D.; Saltz, L.; Casper, E. S.; Spiess, T.: Mullen, E: Woodworth, I : Venuti, R: Zervos, P: Storniolo, A.
M.: Kelsen, D. P. Clin. Cancer Res. 1997, 3,537-543

6. (a) Sasai, $\mathrm{H}$; Tokunaga, $\mathrm{T}$; Watanabe, $\mathrm{S}$; Suzuki, $\mathrm{T}$; Itoh, N:; Shibasaki, M. J. Oig. Chem. 1995, 60, 7388-7389: (b) Masui, M.; Shioiri, T. Tetrahed $r$ on Lent 1998, 39, 5199-5200; (c) Yun, I. M.; Sim, T. B.; Hahm, H. S.; Lee, W. K.; Ha, H. J. J. Org. Chent. 2003, 68, 7675-7680; (d) Shibuya, H.; Kawashima, K.: Narita, N.: Ikeda, M:; Kitagawa, I. Chem. Pham. Bull. 1992, to, 1154-1165; (e) Villard, R.; Fotiadu, F.: Buono, G. Tetrahedron: Asmmethy 1998, 9, 607-611.

7. Zhang, L. H.: Oniciu, D. C.: Mueller, R.; McCosar, B. H.: Pop, E. $\triangle A R H O C$ 2005, 285-291.

8. Sharma, A.; Sunita, G.; Chattopadhyay, S. Tetrahedron Lett. 2007, $48,633-634$

9. Tian, Y. S.: Joo, J. E.: Pham, V. T.; Ham, W. H.; Lee, K. Y. Alch. Pham. Res. 2007, 30, 167-171

10. Kokatla, H. P.; Sagar, R.; Vankar, Y. D. Tetrahedron Lett. 2008, $49,4728-1730$

11. varl den Berg, R. T. B. J. N.; Korevaar, C. G. N.; Overkleeft, H. S.; van der Marel, G. A.; van Boom, T. H. J. Ong. Chent. 2004, $69,5699-5704$

12. Namgoong, S. K; Park, S. K; Lee, S. H. J. Notural Science SHINS 2005, 17, 71-80.

13. (a) David, S.: Malleron, A.; Dini, C. Carbohndrate Res. 1989. 188, 193-200; (b) Auge, C.; David, S.; Malleron, A. Carbolydrate Res. 1989, 188, 201-205.

14. Szeja, W. Swthesis 1985, 983-985.

15. For $\mathrm{LiAlH}_{4}$ reduction of the epoxide in phy tosphingosine, see: (a) Azuma, H.; Tamagaki, S.; Ogino, K. J. Org. Chem. 2000, 65, 3538-3541: for DIBAH reductions of the epoxides in phytosphingosine derivatives, see: (b) Takikawa, H.; Muto, S.; Mori, K. Tewahedron 1998, 54, 3141-3150; (c) Namgoong, S. K: Park, S. K.: Lee, S. H. J. Namal Science SHTNS 2007, 19. 19-26

16. Krishnamurt, S.: Schubert, R. M.: Brown, H. C. J. Am. Chem. Soc. 1973, 95, 8486-8487.

17. Gadikota, R. R.; Callam, C. S.; Lowary, T. L. J. Org. Chem. 2001, 66, 9046-9051. 